\title{
PERSONAL INJURY LITIGATION IN SCHOOL CASES
}

\author{
VerNon X. MiLIER*
}

The case law on school torts has been controlled by propositions of the taught law that are unreal and obsolete in an era of risk-shifting and insuring. Nor is that condition unusual in torts where lawmaking and administration have been interlocked and codification has been superficial. Although workmen's compensation is an exception, lawmen have not produced much comprehensive legislation on torts. ${ }^{2}$

Obviously there is much legislation touching personal injury litigation. There are statutory schemes on survival of actions ${ }^{2}$ and on the allowing of claims because of death by wrongful acts, ${ }^{3}$ some declaratory propositions on fault and defamation, ${ }^{4}$ and occasionally something like a retraction statute in libel ${ }^{5}$ or a statute on extended liability for automobile-using, ${ }^{6}$ but most legislation touching torts is local and special. Much of it is penal, and much of it is in city ordinances. It becomes important in tort cases through the doctrine of negligence per se. ${ }^{7}$ Most of the tort law vocabulary and the taught propositions are derived from an era of individualism when it was supposed literally that torfeasors could pay for their conduct, but this special legislation by ordinance or statute, relating to particular businesses, persons or places, and conditioned by the doctrine of respondeat superior, smacks of status and absolute liability. It becomes practicable when typical risks and costs can be charged to overhead and reduced by insurance. Except for these special regulatory laws and instances such as workmen's compensation or extended liability for automobile-using, lawmaking and codification in torts have not caught up with the facts of life. ${ }^{8}$

Some of the taught-law propositions have been flexible enough and ambiguous enough to allow for case-law trends consistent with the social picture of the I950's

* A.B. 1923, LL.B. x925, University of Minnesota; J.S.D. 1929, Yale University. Member of the Minnesota and Wisconsin bars; Dean and Professor of Law, Catholic University of America.

${ }^{2}$ See the chapter on "Offenses and Quasi Offenses" in the LA. Civil CoDE Arts. 2315-2324. In it are included basic propositions on fault, respondeat superior, and parent and child; something on the responsibility of animal owners and building owners; and the Louisiana propositions on survival of tort actions and actions for wrongful death. There is not much in the chapter that is not declaratory of customary law. As long as the fault thesis is basic in torts, there is little room for codification. Administration, not lawmaking, is the dominant process.

${ }^{2}$ See Comment, I Loyola L. Rev. 84 (I94I).

At common law a cause of action died with the decedent. The death of either one-a prospective plaintiff or a prospective defendant-could affect a case. Some states have been slow to afford relief when a prospective defendant dies before he can be served with process. Cf. Cal. Laws 1949, c. 1380, Caz. Crv. Code \$956. See also Comment, 4 Loyoua L. Rev. 75 (r947).

${ }^{3}$ See Comment, I Loyola I. Rev. 84 (I94I).

- See La. Civil Code Art. 23I5; Cal. Civ. Code $\$ \$$ r708, i7r4.

${ }^{5}$ Cal. Laws I945, c. I489, Cal. Civ. Code, \$48a; 35 Minn. Stat. Ann. \$548.06 (I947).

'Cal. Vehtcle Code $\$ 402$ Deering (1948); 12 Minn. Stat. Ann. \$170.54 (1946).

7 See Ciarence Morris on Torts 64-77 (I954). Cf. Book Review, 42 Calif. L. Rev. 205,206 (1954).

${ }^{8}$ You can second guess yourself on a proposition like this. The comments in note 1 supra are applicable. Except as remedial legislation touches the fault standard, extensive codification is not practicable. 
when cost-sharing and burden-carrying can be spread over wide bases. Without that, it is likely that there would have been more comprehensive and revolutionary kinds of tort legislation. The standard of the reasonably prudent man, the propositions on foreseeability and proximate cause, the Andrews' approach, and even scope of employment, must be administered under the judge and jury system in which issues of law and issues of fact are not clear-cut functionally. Neither judges' decisions nor juries' verdicts become crystallized into precedents. Instructions and verdicts in tort cases reflect administration rather than lawmaking because circumstances of time and place, occasions and relationships, are the vital factors in decisionmaking, and the variety is infinite. Policy choices by judges or jurors are like special legislation for classes of persons on special levels, but the decisions affect only. the parties in the cases. Although much of the law talk in torts is reduced to instructions in everyday cases and stems from an orthodoxy as old as the early nineteenth century, the differences in case law trends over the last fifty years are obvious. Today there are fewer directed verdicts on scope of employment, negligence or not, intervening cause, and remoteness. The results smack of the twentieth century and a highly integrated society. Men are obligated often to their neighbors whatever they may have intended because many obligations among citizens are legal in a society where social action is organic and normal.

All of the taught law of torts is not encompassed in the doctrines of the reasonably prudent man and proximate cause. There have been special rules of limitation such as "fellow-servant" and the rule of Winterbottom v. Wright. ${ }^{10}$ Perhaps by accident, English judges in the eighteenth century began to exploit the doctrine of respondeat superior without which casualty insurance would have been unlikely. There are legalists today who detest the doctrine.11 Perhaps respondeat superior is inconsistent with the fault thesis and it may be an anomaly in the law, but even in the eighteenth century the master-servant relationship was sufficient to absorb some of the costs suffered by strangers through the conduct of some judgment-proof tortfeasors. During the I830's, however, the English judges sensed that employers could be overwhelmed by the costs of servants' torts, particularly when the third persons affected were neither customers nor neighbors of the employer-defendants. ${ }^{12}$ Casualty in-

${ }^{\circ}$ Priestley v. Fowler, 3 M. \& W. 2, 150 Eng. Rep. I030 (Ex. 1838). Priestley $v$. Fowler and the fellow-servant rule are almost synonymous. Nevertheless, it was in subsequent American cases that the rule was expounded and refined. Cf. Farwell v. Boston \& Worcester R.R. Corporation, 4 Metc. 49,38 Am. Dec. 339 (Mass. 1842); Murray v. South Carolina R.R., I McMullan 385, 36 Am. Dec. 268 (S. C. 184I). Sec Miller, The Master-Servant Concept and Judge-Made Law, I LoyoLA L. Rev. 25, 27-30 (I94I).

${ }_{10}^{10}$ M. \& W. 109, 152 Eng. Rep. 402 (Ex. I842).

11 You think of one dean under whom you served many years ago who presented torts as if anything smacking of absolute liability was anathema. He was sure that the doctrine of respondeat stsperior was wrong and that Green v. General Petroleum Company [205 Cal. 328, 270 Pac. 952 (r928)] was an abomination. It is your author's guess that some other lawmen might agree with the old dean about the Green case.

${ }^{12}$ In neither of the two cases-Priestley or Winterbottom-did the court announce a principle as such, but in several of their judgments the Barons expressed their fears as to the consequences if responsibility were not limited absolutely. 
surance was unknown in 1830. Priestley $v$. Fowler and Winterbottom v. Wright were the immediate results.

The fellow-servant rule, the rule on privity of contract, and the two leading cases are interesting to lawyers even today. So are the refinements and the exceptions to the rules, but an exposition of that story is beyond the scope of this paper. Almost all of the learning on the fellow-servant doctrine is obsolete because of workmen's compensation, although Winterbottom $v$. Wright is a potent legalism still in spite of Judge Cardozo and the MacPherson case. ${ }^{13}$ One kind of legalism can generate another. Breach of warranty in the law of sales has afforded an escape from Winterbottom $v$. Wright. ${ }^{14}$ The breach of warranty digression permits results consistent with status obligations and risk-shifting possibilities. ${ }^{15}$ It points up also the inadequacies and the artificialities of the literal taught law.

Litigation in school cases has been affected by taught-law doctrines comparable to the fellow-servant rule and the rule on privity of contract. At least in school cases the taught-law rules are negative, and the defenses are sufficient to exclude a plaintiff from relief without an inquiry into the merits of a case. Also in school cases decisions have hardened into precedents carrying the weight of authority and allowing for refinements and exceptions and stimulating some planning of remedial legislation. In the private school cases the absolute defense is the doctrine of immunity from suit for charitable corporations. ${ }^{16}$ In public school cases it is the doctrine of state immunity. ${ }^{17}$ Reasons for the doctrines seem more plausible, perhaps, than reasons offered for the fellow-servant rule and Winterbottom $v$. Wright. It is

${ }^{13}$ MacPherson v. Buick Motor Co., 217 N.Y. 382, XII N.E. I050 (1916). With this case you like to compare Judge Sanborn's opinion in Huset v. J. I. Case Threshing Mach. Co. [120 Fed. 865 (8th Cir. 1903)]. You think Sanborn was the legalist par excellence in that case where he was trying to justify the wise public policy supporting the privity of contract limitation and trying also to pour logic into the exceptions and refinements. You wonder about the case and whether or not the plaintiff's lawyer ever could build a record to support a finding that someone in the company knew when the machine was processed that it could not be used. The case was decided for the plaintiff on a demurrcr to a complaint.

14 The possibilities are indicated in a New York case: Ryan v. Progressive Grocery Stores, 255 N.Y. 388, I75 N.E. 105 (193I). The purchaser had asked for a particular brand of wrapped bread. He did not rely on the retailer's recommendation. There was a pin in the loaf, and the plaintiff suffered a personal injury when he cut his mouth on the pin. The retailer was responsible, the court said, because of the breach of the warranty of merchantability. The absolute liability implications are obvious. Some courts would restrict the retailer's responsibility to those instances where he recommends the purchase. See Curtiss Candy Co. v. Johnson, 163 Miss. 426, I4r So. 762 (1932). In foodproduct cases the California courts have accepted the result of the New York case although the judges have discussed only the warranty of quality. Gendraux v. Maurice Mercantile Co., 4 Cal.2d 206, 47 P.2d 708 (x935); Vaccarezza v. Sanguinetti, 7x Cal. App. 2d 687, I63 P.2d 470 (1945) (purchaser was successful on the breach of warranty theory in a personal injury case against both retailer and processor). On the warranty of fitness theory against other kinds of merchandisers, see: Sears, Rocbuck \&t Co. v. Marhenke, r2I F.2d 598 (9th Cir. r94I); and Deffebach v. Lansburgh \& Bro. Co., 150 F.2d 59I (D.C. Cir. 1945).

${ }^{15}$ See Traynor, J., concurring in Escola v. Coca Cola Bottling Co., 24 Cal.2d 453, 462, 150 P.2d 436, 440 (1944).

${ }^{10}$ It is important here to emphasize a condition in the case law on charities. Most of the litigation on charities relates to hospitals rather than to schools or churches or social clubs, but the propositions are effective in all charity cases. See 10 AM. JuR. 687 et seq.

${ }^{17} 47$ AM. Jur. 334 et seq. 
argued that the assets of a private charity ${ }^{18}$ cannot be wasted through litigation and that the normal functioning of government cannot be reduced through the levying of executions and the running up of costs in litigation that is not related to the public interest. All of which sounds academic in 1954 except when some judge, relying on authority, offers a trite exposition of the taught law.

In the private school cases judges are becoming realists. Trends in that direction have been noticeable in recent years. Insurance possibilities have been detected as sufficient to justify a break with authority and precedent. ${ }^{19}$ But the path to reality has been devious. Many years ago it was decided in some courts that strangers to the trust are not affected by the special privilege of the charity. ${ }^{20}$ In school cases that could protect tradesmen and visitors but not pupils or teachers. ${ }^{21}$ Charities cannot rely on the immunity defense when beneficiaries have been injured by incompetent or untrained employees. ${ }^{22}$ Sometimes private charities have bargained with their insurers that the companies shall not assert a private charity's defense when an insurer's counsel represents the charity as a defendant in a tort case. The Illinois court has recognized that kind of contract as binding on the insurer. ${ }^{23}$ In Maryland there is a statute in which the legislature has prescribed that an insurance carrier cannot assert a charity's defense of immunity from suit. ${ }^{24}$ There has been some litigation under the statute affecting public institutions like schools and hospitals, and there is reason to believe that the Maryland courts will recognize the

${ }^{18}$ The definitions of a charity are broad and flexible. A non-profit school is a charity although tuition rates are high. That a school or a hospital is subsidized or endowed in part and that some free beds or scholarships are offered to patients or students is evidence of an institution's status. Jurjevich v. Hotel Dicu, II So.2d 632, 634 (La. App. 1943). The selling of religious articles at a church does not affect the status of the church. Cullen v. Schmit, r39 Ohio St. 194, 39 N.E.2d I46 (1942). But a charity's immunity does not extend to cover the operating of commercial properties although income from the properties may be used to subsidize the school. Rhodes v. Millsaps College, 779 Miss. 596, I76 So. 253 (1937). Also the immunity does not cover the operating of motor vehicles in carrying on thẻ functions of the charity. Winslow v. Veterans of Foreign Wars Home, 328 Mich. 488, 49 N.W.2d 19 (r950).

${ }_{10}$ Noel v. Menninger Foundation, 267 P.2d 934 (Kan. 1954); Pierce v. Yakima Valley Memorial Hosp. Ass'n, 43 Wash. 2d I62, 260 P.2d 765 (1953); McMullen v. Ursuline Order of Sisters, 56 N.M. 570, 246 P.2d 1052 (I952); Moeller v. Hauser, 54 N.W.2d 639 (Minn. I952); Malloy v. Fong, 37 Cal.2d 356, 232 P.2d 24I (195I); Durney v. St. Francis Hospital, 83 A.2d 753 (Del. Sup. Ct. I95I); Foster v. Roman Catholic Diocese of Vermont, II6 Vt. I24, 70 A.2d 230 (1950); President and Directors of Georgetown College v. Hughes, 130 F.2d 810 (D.C. Cir. 1942). Nevertheless, some courts are adamant and cling still to the old judge-made rule. Jones v. St. Mary's Roman Catholic Church, 7 N.J. 583, 82 A.2d I87 (195I); Bond v. City of Pittsburgh, 368 Pa. 404, 84 A.2d 328 (I95I). Cf. Tuengel v. City of Sitka, 118 F. Supp. 399 (D.C. Alaska, 1954) (court followed the current trend in charity cases against a state hospital).

${ }^{20}$ Winslow v. Veterans of Foreign Wars Home, 328 Mich. 488,44 N.W.2d I9 (1950); Nickerson v. Laconia Hospital Ass'n, 96 N.H. 482, 79 A.2d 5 (r95r); Walker v. Memorial Hospital, r87 Va. 5, 45 S.E.2d 898 (1948).

${ }^{21}$ But see Southern Methodist University v. Clayton, I42 Tex. 179, I76 S.W.2d 749 (I943). The Texas court refused to recognize any exceptions, even for strangers, when a private school was a defendant.

${ }^{23}$ Haliburton v. General Hospital Society, 133 Conn. 6I, 48 A.2d 26r (I946); see Esposito v. Henry H. Stambaugh Auditorium Ass'n, 77 N.E.2d IIr, II2 (Ohio App. 1946).

${ }^{23}$ Wendt v. Servite Fathers, 332 Ill. App. 6r8, 76 N.E.2d 342 (I947) (a school case); Moore v. Moyle, 405 Ill. 555, 92 N.E.2d 8x (1950).

${ }^{24}$ Md. Laws 1947 , c. $900, \mathrm{MD}$. Cove art. $48 \mathrm{~A}, \S 82$ (I95I). 
law as effective even in the public agency cases. ${ }^{25}$ In Tennessee ${ }^{26}$ and Colorado ${ }^{27}$ the courts have devised a routine which may help judges in other states to satisfy their professional scruples. Judgment at the suit of a private person can be entered against a school, a hospital or a church, but the judgment can be satisfied only out of assets which are not related to trust. Contracts for casualty insurance are such assets.

Most of these exceptions by devious paths are important only when a charity is insured. Important as that is in the great quantity of cases, it leaves the basic premise unaffected. The exceptions are refinements of the rule, and the rule remains a part of the taught law. Currently some courts are reaching directly for the target. ${ }^{28}$ The rule is bad because charities, like other institutions, can purchase casualty insurance, and overhead costs are relatively low. ${ }^{29}$ But judges have had to labor hard to reach the goal. The experiences in the State of Washington, perhaps, are typical. Exceptions were recognized, but until I953 the supreme court was adamant. Several times it was solicited to change the rule. ${ }^{30}$ Finally, when the older case law was overturned, two of the judges dissented and called for help from the legislature. ${ }^{31}$ Nevertheless, prophecy in private school cases is easy. Most courts will discount the immunity defense in all charity cases. If judges do not respond with case-law openings, legislation will be forthcoming. The text of remedial statutes can be simple and positive. ${ }^{32}$ Alert legislators will not be stymied long by judge-made legalisms. ${ }^{33}$

The public school cases cannot be diagnosed so easily. Nor are the remedies simple. Remedial legislation for these cases demands some planning and correlating with other programs because the doctrine of state immunity on some levels is not academic. That the "king can do no wrong" is good history. As a practical solu-

${ }_{25}^{25}$ Thomas v. Board of County Comm'rs, $200 \mathrm{Md}$. 554, 92 A.2d 452 (1952). In this case a county institution was the defendant. The case was settled for the plaintiff after this appeal in which a new trial was ordered to permit the plaintiff to amend his pleadings to allege the fact of insurance and to argue on the statute. So the author was informed by plaintiff's counsel.

${ }_{28}$ Anderson v. Armstrong, 180 Tenn. 56, I7I S.W.2d 401 (1943).

${ }^{27}$ St. Luke's Hospital Ass'n v. Long, 25 Colo. 25, 240 P.2d 917 (I952).

${ }^{28}$ See the cases cited in note Ig, supra.

${ }^{20}$ See Hamley, J., in Pierce v. Yakima Valley Memorial Hospital Ass'n, 43 Wash. $2 d$ I62 at I72, 260 P.2d 765, at 77x: "The taking of liability insurance could create no liability where none before existed. . . . The fact that the protection afforded by liability insurance is now available to charitable institutions generally is nevertheless appropriate for consideration, where the question is whether, as a matter of public policy, such institutions need immunity."

${ }^{30}$ Magnuson v. Swedish Hospital, 99 Wash. 399, 169 P.2d 828 (1918); Miller v. Mohr, 198 Wash. 6rg, 89 P.2d 807 (1939); Weiss v. Swedish Hospital, 16 Wash. 2d 446, 133 P.2d 978 (1943).

${ }^{31}$ Pierce v. Yakima Valley Memorial Hospital Ass'n, 43 Wash. 2d 162, 260 P.2d 765 (1953). This is an interesting reaction. It is so typical that it cannot be described as a phenomenon. The taught-law propositions are judge-made originally. Thereafter classical minded judges refuse to re-examine them however inadequate they may be in the light of subsequent experiences. To the legalist that represents the effect of precedent in a government of law. It is an impossible approach in the ficld of constitutional interpretation. In the area of private civil and commercial law the combination of judge-made revisions and refinements together with remedial legislation, piece by piece, is sufficient usually to let political action approach the level of the common good.

${ }^{32}$ The Maryland statute [Md. Laws 1947, c. 900 , cited in note 24 stupra] is a three-quarters kind of remedy.

${ }^{33}$ The comments in note $3 x$ supra are pertinent additions also to the text at this place. 
tion in law suits, it sounds unreal. But the idea of state immunity can serve a useful function even today, if there is afforded with it some other routine as a substitute for ordinary litigation in adjusting disputes between private citizens and political agencies. Torts in school cases are affected by the doctrine only by coincidence, and it has been in tort cases that judges have devised some case-law exceptions. Municipalities and counties cannot escape the cost of torts committed by their agents who are engaged in proprietary functions. ${ }^{34}$ The classifying of functions into public or private, governmental or proprietary, is arbitrary in practice and may not be related to basic differences, but the possibilities indicate a kind of practical solution in some instances where local agencies can maintain casualty insurance programs. Nevertheless, these possibilities in school cases have been proscribed. Authority is onesided; maintaining schools is a public function. ${ }^{35}$ Nor have the courts relented to classify many incidents of school administration as proprietary, even when a project is operated for a profit. ${ }^{36}$ An injured patron, for example, who has paid an admission fee to a school game, cannot evade the immunity defense. ${ }^{37}$ Although the public function status is not effective against a claim of nuisance, the nuisance must have a property association. ${ }^{38}$ Plaintiffs who complain about noise, light, windowbreaking, and playground-using must be neighbors. All of which does not suggest general nuisance possibilities. Bad maintenance is like ordinary negligence. ${ }^{39}$

Although there is legislation in many states touching public agency torts, much of it relating especially to schools, there is nothing in any state as broad as the Federal Torts Claims Act. ${ }^{40}$ At the top level it is true still that the king can do no

3438 AM. JuR. 260 et seq., 266.

${ }^{35}$ Bragg v. Board of Public Instruction, I60 Fla. 591, 36 So.2d 222 (1948); Lovell v. School District, 172 Ore. 500, 143 P.2d 236 (x943); Farmer v. Poultney School District, I13 Vr. 147, 30 A.2d 89 (x943); Daszkiewicz v. Board of Education, 301 Mich. 212, 3 N.W.2d 7I (1942); Odil v. Maury County, '175 Tenn. 550, 136 S.W.2d 500 (1940). Cf. Bingham v. Board of Education, 223 P.2d 432 (Utah r950) (court sustained the immunity defense over the protest of a dissenting judge). Except for the dissenting opinion in the Utah case, judges have not been willing to sacrifice the public function category in school cases.

${ }^{36}$ Thompson v. Board of Education, 12 N.J. Super. 92, 79 A.2d 100 (1951). See Elias v. Norton, 53 Ohio App. 38, 4 N.E.2d 146 (1936) (plaintiff was allowed to go to trial in an action against the members of the board after he had alleged that board members individually operated the school lunchroom for a profit).

${ }^{37}$ Reed v. Rhea County, 189 Tenn. 247, 225 S.W.2d 49 (1949); Rhoades v. School District, II5 Mont. 352, I42 P.2d 890 (1943); cf. Smith v. Hefner, 235 N. C. I, 68 S.E.2d 783 (x952) (school trustees had leased the athletic field to a professional club and the plaintiff was injured at a ball game). But see Watson v. School Dist., 324 Mich. I, 36 N.W.2d I95 (1949) (court recognized the incidental profit possibility as sufficient to affect the immunity defense even when the injured plaintiff was a student).

${ }^{38}$ Neiman v. Common School District, I7I Kan. 237, 232 P.2d 422 (I951); Ness v. Independent School District, 230 Iowa 77x, 298 N.W. 855 (I94I); cf. Carter v. Lake City Baseball Club, 218 S.C. 255, 62 S.E.2d 470 (1950) (injunction granted against the leasing ultra vires of the athletic field by school board to a baseball club).

${ }^{30}$ Braun v. Trustees of Victoria Indep. School District, II 4 S.W.2d 947 (Tex. Civ. App. I938); Larsen v. Independent School District, 223 Iowa $69 \mathrm{x}, 272$ N.W. 632 (1937) (plaintiff's decedent was a special guest invited to deliver an address to the student body). But see Bush v. City of Norwalk, 122 Conn. 426, 189 Atl. 608 (1937) (the result was conventional but court suggested that bad maintenance and nuisance conditions could be sufficient for a case).

${ }^{\circ}$ For the District of Columbia Congress has prescribed a scheme for settling personal injury claims by administrative action of the Commissioners. The top figure is $\$ 10,000$, which is not much. Even 
wrong. ${ }^{402}$ There is no breakdown into governmental or proprietary functions, and except for workmen's compensation and special legislation for particular litigants, ${ }^{41}$ remedial legislation is directed usually toward the municipal or county levels and toward public corporations.

- In the State of Washington there is a general statute affecting all agencies under the top level. ${ }^{42}$ School cases are covered ${ }^{43}$ and governmental immunity has been spiked, but the statute is interpreted strictly in instances that would suggest inferences of negligence against commercial proprietors because of bad maintenance, ${ }^{44}$ and the legislature has excepted from the statute certain school cases involving the use of athletic equipment and playground apparatus. ${ }^{45}$ In Oregon there is a statute literally much like the one in Washington, ${ }^{46}$ but that statute has been interpreted as permitting only a classifying of instances, case by case, according to governmental or proprietary functions. ${ }^{47}$ The statute is declaratory merely of what is permitted by case law in most of the other states.

In Washington the text of the statute is simple. In New York and California the legislation is more intricate and is devised especially for school cases, although in both instances the statutes are correlated with other special laws affecting other public agencies. Under the California statutes all local agencies can be charged in tort for bad maintenance where there is evidence of long-time bad conditions. ${ }^{48}$ Literally the law is devised to exclude inference of negligence possibilities. ${ }^{40}$ School districts are included among the public agencies affected, and pupils are included among

so it represents a recent boost from $\$ 5,000$. I D. C. Cope $\$$ I-902, I-904 (195I) and (Supp. I953). These sections cover school cases as well as all other public agency tort claims.

10. Except in New York. See N.Y. CT. CL. AcT. $\$ 8$.

1 Before the Federal Tort Claims Act was enacted it was customary for Congress to pass special legislation for personal injury claimants. Cf. State ex rel. Green v. Board of Education, 133 W. Va. 750, 58 S.E.2d 279 (1950) (the legislature had provided for the adjusting of claims through an administrative agency in all governmental immunity cases and the total annual appropriation for all claims was $\$ 50,000)$. In Louisiana it is not unusual for the legislature to authorize by special act the processing of a lawsuit by a claimant against a state agency. See the two opinions in Whitficld v. East Baton Rouge Parish Board, the first case, 23 So.2d 708 (La. 1945), and the second case, 43 So.2d 47 (La. 1949). In the first attempt the board was successful against the plaintiff on the immunity defense. Thereafter action against the board by this plaintiff was authorized by act of the legislature, and in the second case the board was successful on the merits.

"2 WASH. CODE $\$ 408.120$ (Rem. I95x).

«s Briscoe v. School District, 32 Wash. 2d 353, 20r P. 2d 697 (r949).

44 Morris v. Union High School District, I6o Wash. I2I, 294 Pac. 998 (x93I); cf. Walter v. Everett School Dist., r95 Wash. 45, 79 P.2d 689 (1938) (a WPA instructor was not a school teacher and the district was not responsible under the statute for his conduct).

${ }^{45}$ WASh. CODE $\$ 28: 58-030$ (Rem. 195I). Cf. Snowden v. Kittitas County School District, 38 Wash. 2d 69I, 23I P.2d 62I (x95I).

10 ORe. COMP. LAwS ANN. \$8-702 (Supp. I943).

${ }^{47}$ Lovell v. School District, I72 Ore. 500, I43 P.2d 236 (r943); cf. Blue v. City of Union, I59 Orc. 5, 75 P.2d 977 (1938).

is CAL. Gov'T CODE $\$ 5305 x$ (Deering 195I).

"School cases are affected by the inference of negligence limitations. Hough v. Orleans Elementary School District, 62 Cal. App. $2 \mathrm{~d} \mathrm{I}_{46} \mathrm{r}_{44}$ P.2d $38_{3}$ (r943). A school board is not responsible for the torts of students. Reithardt v. Board of Education, 43 Cal. App. 2d 629, III P.2d 440 (r94I) (no evidence of inadequate supervision by teachers). 
the persons covered. ${ }^{50}$ There are special sections in the California statutes affecting school districts only. ${ }^{51}$ Governing boards as such are charged with responsibility for the negligence of officers or employees, but intentional torts are not included. ${ }^{62}$ Claims for reimbursement must be presented to the board within ninety days or lawsuits cannot be litigated. ${ }^{53}$ Members of a board are not personally responsible for tort claims but board members can be tortfeasors individually, ${ }^{54}$ and governing boards are authorized to insure against liability. ${ }^{55}$

In New York the legislature has prescribed specifically in several sections and in different statutes that boards of education shall "save harmless" teachers, supervisors, officers or employees from damages arising out of negligence resulting in personal injury or property damage. ${ }^{56}$ These statutes relate only to schools. One section affects schools in districts where the population exceeds a million, ${ }^{57}$ and the others cover all of the other districts. ${ }^{58}$ In effect New York State is divided by the legislature between New York City and the rest of the state. In the section affecting the city there is in addition to the "save harmless" clause a direct liability provision. In the sections pertaining to the other areas it is provided that district boards can arrange for insurance or can act as self insurers. Under either arrangement the courts have held that a school district is a proper party in a tort case. In practice the results in the cases affecting the city and those affecting the other areas are approximately the same. ${ }^{59}$ And there is reason to conclude that the New York cases are not loaded against res ipsa loquitur and inferences of negligence. The cases are controlled also by other statutes in which regulations are effected about school equip-

${ }^{20}$ Cal. Gov't Code $\$ 53050$ (Deering 195I).

"CAl. Educ. CODE $\$ \$ 1007$, 1008, 1026-1029 (Deering 1952).

${ }^{2}$ CAL. EDuC. CODE $\$ 1007$ (Deering 1952). The cases are many and the interpretations are broad except as they are controlled by actual knowledge limitations. See Bellman v. San Francisco High School District, II Cal.2d 576, 8r P.2d 894 (I938); Hanson v. Reedley Joint Union High School District, 13 Cal. App. $2 d 643$, II I P.2d 415 (I94I) (district responsible in a case involving a privately owned car because school authorities had permitted and paid for the carrying of a student from the school to her home).

${ }^{63}$ CAL. Edvc. CODE $\$ 1007$ (Deering 1952). It is difficult to appraise the case law on notice. If action is begun within the 90 day period, the filing of notice is not important. Porter v. Bakersfield \& Kern Electric Ry., 36 Cal. $2 \mathrm{~d} 582,225$ P.2d 223 ( 5950 ). The notice itself may be phrased informally. Ridge v. Boulder Creek Union Junior-Senior High School District, 6o Cal. App. 2d 453, 140 P.2d 990 (r943). Nevertheless, the filing of some sort of written notice is esssential, and a plaintiff who has not filed is barred even when it appears he was misinformed about his claim by the district's insurer. Brown v. Sequoia Union High School, 89 Cal. App. 2d 604, 20 I P.2d 66 (1949).

${ }^{6} \mathrm{CAL}_{\text {L }}$. EDuc. CODE $§ 1026$ (Deering 1952). For a possibility indicating how board members can be tortfeasors, see Whit v. Reed, 239 S.W.2d 489 (Ky. I95I). For a case where a school teacher was a tortfeasor in a maintenance case and was covered by personal liability insurance, see Brooks v. Jacobs, I39 Me. 37I, 3 I A.2d 414 (I943). The author was informed by the plaintiff's attorney that the insurer settled the case after a new trial was ordered by the appellate court.

it Cal. Educ. Code $\$ 1029$ (Deering I952).

${ }^{60}$ N.Y. Edurc. LAW $\$ 2560,2562,3023,3024$.

${ }^{67} I d . \$ 2560$.

${ }^{68}$ Id. $\$ \$ 3023,3024$.

${ }^{80}$ Under the New York City section, see Ohman v. Board of Education, 300 N.Y. 306, 90 N.E.2d 474 (1949); and Reeder v. Board of Education, 265 App. Div. 158, 38 N.Y.S.2d 55 (2d Dep't 1942). Under the other sections, see Miller v. Board of Education, 29I N.Y. 25, 50 N.E.2d 529 (I943); and Edkins v. Board of Education, 287 N.Y. 505, 4I N.E.2d 75 (1942). 
ment, curriculum, personnel and such, leaving little discretion to board members. ${ }^{00}$ If any instance of personal injury or property damage can be related to a default under these other statutes, it is evidence of negligence on the part of board members.

Under the New York, California and Washington statutes much of the punch is gone from the immunity defense in school cases. In New Jersey there is a "save harmless" statute, ${ }^{61}$ and the New Jersey experiences illustrate the inadequacies of this kind of remedy. Usually a remedial statute like it must be correlated with other regulations, and the text of such a statute may be literally restrictive. Both of these factors have affected the cases under the statute in New Jersey. First of all the New Jersey legislation is drafted literally in the interest of teachers and administrative personnel, which excludes janitors and maintenance workers. School boards are directed to provide counsel for all employees who are defendants in tort actions. ${ }^{02}$ Boards can purchase insurance protection for employees, or they may act as self insurers, but tort claims against public schools are also controlled by another statute. ${ }^{03}$ School districts cannot be charged with responsibility directly. Consequently the New Jersey courts have held that a school district is not a proper party when a teacher is a defendant. ${ }^{64}$ Perhaps most often school districts contract directly with insurance companies for protection covering teachers and board members as insureds. In that event whether or not a school district can be made a party is academic. But when there is no insurance contract behind the law suit, a plaintiff's lawyer is faced with a dilemma. If he does sue a school teacher and if he does get a judgment against the teacher, how does he reach the district's obligations? Literally the school district must reimburse the teacher for what his tort has cost him. Nevertheless, it is not likely that any court would permit a district to evade responsibility where a school teacher is judgment-proof..$^{65}$ Supplementary proceedings in aid of execution comparable to garnishment should be an adequate remedy.

The simple "save harmless" kind of statute is not widely used. In addition to the one in New Jersey, there is one like it in Connecticut. ${ }^{68}$ Currently there is no case law under the Connecticut statute. As a remedial statute this kind of scheme does not erase sufficiently the effects of the immunity defense. Even when a school district can be included as a party, if responsibility depends on there being an ascer-

\footnotetext{
${ }^{\circ 0}$ Sec particularly Edkins v. Board of Education, 287 N.Y. 505, 4I N.E.2d 75 (I942); and Govel v. Board of Education, 267 App. Div. 621, 48 N.Y.S.2d 299 (3d Dep't 1944), aff'd, 293 N.Y. 928, 60 N.E.2d I33 (I944). As illustrative of the statutory regulations, see the general powers and limitations on board members in Section 868 of the Education Law, and see the references to Section 256 of the Labor Law and Sections 695 and 696 of the Education Law which were discussed in the two cases cited.

${ }^{61}$ N. J. Stat. Ans. $\$ 18: 5-50.4$ (1940).

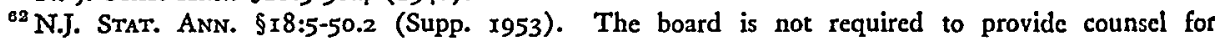
teachers who have inflicted corporal punishment on pupils. See also N.J. Stat. ANN. \$18:5-50.3 (1940).

${ }^{63}$ N.J. Stat. ANN. $\$ 1$ 8.5-30 (1940)

6ripus v. Peterson, II N.J. Super. 282, 78 A.2d I49 (1950); Falcone v. Board of Education, I7 N.J. Misc. 75, 4 A.2d 687 (1939).

${ }^{65}$ See Falcone v. Board of Education, I7 N.J. Misc. at 77, 4 A.2d at 688-689 (1939).

${ }^{\circ 8}$ Conn. Gen. STAT. tit 13 , c. $7 x, \$ \S 1494, I 495$ (r949) as amended, Conn. Laws 1949, c. 163 and Conn. Laws r95r, c. Ir3. There is no case law under the Connecticut statute. Apparently all employecs are covered, and there is some doubt as to whether or not instances of corporal punishment are included.
} 
tained tortfeasor, either teacher or janitor, there is still left unaffected by the statute most of the cases arising from defective premises. ${ }^{67}$ It is not practicable often to identify one person as a tortfeasor in a bad maintenance case. The cases under the New York "save harmless" statute do point a way to inference of negligence possibilities.

Automobile-using generates well over half of all personal injury litigation. Neither judges nor legislators have been so stubborn that they have not tried to control the immunity defenses in vehicle cases. ${ }^{68}$ Much of the classifying into public and private functions has been effected in these cases. ${ }^{69}$ In many states there are laws touching school bus driving and authorizing payments by school districts for limited insurance protection. The whole subject of bus-driving, automobile casualty risks, and insuring is the subject of another paper in this symposium. It is sufficient here to indicate that this legislation is remedial in a limited way. Sometimes school districts are permitted to insure for limited sums, ${ }^{70}$ or it is specified that bus drivers shall be required to furnish indemnity bonds. ${ }^{71}$ Currently there is a trend toward statutory waiver of the immunity defense in school bus cases. ${ }^{72}$ There is reason to argue that the interest of the districts in the operation of the school buses is sufficient to justify expenditures for premiums even without an authorization statute. All of which suggests that much of this legislation is like a curative statute. Judges are helped by it to escape from some nice arguments on constitutional law. The bus statute in Kentucky has real teeth. In that statute it is provided that insurers shall be bound to pay the claims of injured persons directly and that the school districts must require private carriers to be insured against liability. ${ }^{73}$ The Kentucky court has held that board members are personally responsible for tort claims when a private carrier is uninsured and is judgment-proof..$^{74}$

The "safe place" statute in Wisconsin ${ }^{75}$ has had some effect on the immunity defense in school cases. According to the text of the statute it would seem to be effective primarily in the interest of employees and against private employers, but it covers also persons responsible for the maintenance of public buildings. Although

${ }^{67}$ See, for example, a case like Falcone v. Board of Education [I7 N.J. Misc. 75, 4 A.2d 687 (1939)]. The plaintiff was injured when a large slab of stone fell upon her in the girls' lavatory. Even if maintenance employees were covered by insurance in such a case, it would be difficult to identify any one of them as the tortfeasor responsible for the bad condition. Cf. Hough v. Orleans School District, 62 Cal. App. $2 d$ r 46, r 44 P.2d 383 (1943).

${ }^{\circ 8}$ As illustrative statutes in which the immunity defense has been waived when public agency vehicles are used, see Car. Vehicle Code $\$ 400$ (Deering I948); MinN. Stat. ANn. \$47x.42 (Supp. 1953). See also WIS. STAT. $\$ 85.095$ (195I). But in Wisconsin now the legislature has prescribed an administrative scheme for adjusting against public agencies claims derived from automobile using. Wis. STar. $\$ 85.095$ (x953).

${ }_{00} 38$ Ax. Jur. 308 et seq.

70 Arrz. Code ANn. \$54-434 (Supp. 1951); 13 Iowa Code ANn. \$285.10(6) (Supp. 1953); 4 Mont. Rev. Code $\$ 75-3406$ (I947); OkI.A. Stat. ANn. tit. 70, \$9-7 (1950).

${ }^{71} 8$ Tex. Civ. Stat. art. $2687 \mathrm{a}$ (Vernon, 1951); 2 Tenn. Code \$2495 (Williams, 1934). But see Tenn. Laws 1947 , c. $92, \$ 13$. Now all school buses in Tennessee must be insured against liability.

${ }^{73}$ Conn. Gen. Stat. $\$ 8296$ (1949); 6 Idaho Code Ann. 33-80I(6) (1947).

${ }^{73} \mathrm{Ky}$. Rev. Stat. \$160.310 (1953).

7 Bronaugh v. Murray, 294 Ky. 715, 172 S.W.2d 59r (1943).

${ }^{7}$ Wis. Stat. §I01.06 (1953). 
the Wisconsin court has held that the statute is effective in maintenance cases even against school districts, ${ }^{76}$ still the law is a special one and subject to limited application. Sometimes the limitations seem artificial. The Wisconsin court has said that a flag pole on the school grounds is not a part of a school building. Consequently the immunity defense was good against a school boy who was injured when a flagpole top fell upon him while he was playing in the school yard. ${ }^{77}$ Within the precise limits of "safe place" possibilities, this kind of statute allows for all cases consistent with res ipsa loquitur and inferences of negligence.

In Louisiana there is another kind of general statute which has reduced the effects of the immunity defense in private charity cases. ${ }^{78}$ Conceivably the law can have some effect in public agency cases. Under the Louisiana statute insurers can be sued directly as defendants in all casualty cases, and it is not necessary that the insured tortfeasors be joined as defendants. The insurers cannot assert defenses which are personal to the insured, and the immunity defense is that kind. ${ }^{70}$ Only when a private charity is insured can this statute be effective. Insurance protection can be purchased also for public agencies. ${ }^{80}$ It is arguable always that there must be statutory authorization for such insurance-carrying because otherwise there is a spending of public funds for a purpose that is not public. It is to be hoped that courts nowadays will not labor long over that kind of argument. Casualty insurance covers litigation costs, and affords protection also against the costs of judgments. The public interest is obvious.

This list of statutory proposals is not long, nor is the variety great. Some of it has affected school cases only by coincidence, but some of it has been planned for schools primarily. What is surprising is that there has not been more planned legislation. Bus statutes have been drafted specially for school cases, but it is doubtful that any legislature has planned such a statute as a first step in any comprehensive scheme. Most of our thinking in school torts, most of our arguing, and most of our legislating has been conventional. We have not tried to reach far for remedies.

It is surprising also that there has not been more insurance writing for public employees paid for out of public funds. ${ }^{81}$ It can cost much, but private entrepreneurs

70 Heiden v. Milwaukee, 226 Wis. 92, 275 N.W. 922 (1937).

${ }^{27}$ Lawver v. Joint District, 232 Wis. 608, 288 N.W. I92 (1939).

${ }^{78}$ LA. Rev. StaT. (1950) $\$ 22: 655$, as amended by La. Laws 1950 , c. $54 \mathrm{r}$ r. See Bourgeois v. Indemnity Ins. Co., 60 So.2d 718 (La. App. 1952) (a private school case in which the insurer was the defendant and where judgment was entered on the merits for the company).

${ }^{70}$ Edwards v. Royalty Indemnity Co., 182 La. I7I, I6I So. I91 (1935); see also Burke v. Massachusetts Bonding \& Ins. Co., 209 La. $495,502,24$ So.2d 875, 877 (1946).

${ }^{80}$ Sec Rome v. London \& Lancashire Indemnity Co., 169 So. 132 (La. App. r936) (insured was a public corporation established to administer public park facilities).

${ }^{81}$ The author has been informed by underwriters that it is customary for school districts to carry insurance protection although the possibilities are negligible that personal injury plaintiffs can proceed to judgment against them. Also he has been told that it is usual for insurers to include board members as insureds at no extra cost or for a nominal charge. Board members can be tortfeasors, although the possibilities are indicated rather by the facts of the Kentucky case described in note 54 stipra than by the routines of the New York court described in the text and also in note 59 supra. The underwriters say that it is not customary for school districts to purchase protection for employees, school teachers, janitors, or other employees except in the few states where there are the "save harmless" statutes. 
accept that kind of cost as a normal overhead expenditure. Conventional lawmen like to struggle over public purpose arguments. Perhaps we shall have to settle for general authorization statutes like the bus laws. ${ }^{82}$ However, in an era when the law is driving toward enterprise liability, with insurance costs calculated as overhead risks, it is not likely that public agencies will be isolated long. Perhaps there will be more remedial legislation for school cases like that in California and New York, or more legislation like the statutes in Louisiana, Washington, and Wisconsin. Perhaps underwriting practices will make all immunity defenses academic. Certainly the public interest would seem to point to common standards in all kinds of casualty cases. Perhaps by the time lawmen have leveled off the inequities in school cases, everything in the personal injury field will look like workmen's compensation. ${ }^{83}$

${ }^{82}$ Perhaps the Pennsylvania statute is a straw in the wind. It was enacted in $195 \mathrm{I}$ ( $\mathrm{Pa}$. Laws 1527 §). School districts are authorized to purchase insurance protection against negligence for all employees. 7 PA. Stat. ANN. \$7-774(b) (Purdon, Supp. I953).

${ }^{83}$ All of which may happen faster than some lawmen expect. In certain areas the trend toward big verdicts or adequate awards (as plaintiff's lawyers would describe them) is affecting the cost of casualty insurance. Absolute liability and standardized schedules may be a solution even in the opinion of insurance underwriters. See Miller, An Interpretation of the Act of 1939 (FELA) to Save Some Remedies for Compensation Claimants, i 8 LAw \& Contemp. Prob. 24I, 254-255 (1953). 